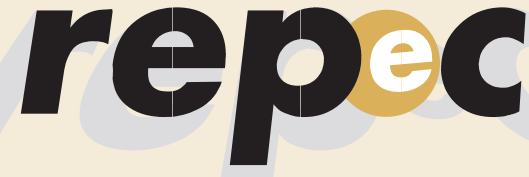

REPeC, Brasília, v. 11, n. 1, diretrizes aos autores p. 127-129, jan./mar. 2017

Disponivel online em www.repec.org.br
Revista de Educação e Pesquisa em Contabilidade

Journal of Education and Research in Accounting

Periódico Trimestral, digital e gratuito publicado pela Academia Brasileira de Ciências Contábeis

ISSN 1981-8610

\title{
Diretrizes aos autores
}

\section{Regras para submissão de Artigos}

Para submissão de artigos à Revista de Educação e Pesquisa em Contabilidade - REPeC, os autores devem seguir as normas e critérios definidos pela REPeC. A partir de Janeiro de 2013 são seguidas as normas da American Psychological Association (APA) no que se refere às citações e referências bibliográficas. Serão rejeitadas as submissões que não estiverem de acordo com as normas.

Os artigos submetidos à Revista devem ser inéditos, ou seja, não terem sido publicados ou enviados a outro periódico.

Os artigos podem ser redigidos em português, inglês ou espanhol, com no mínimo 5.000 e máximo 10.000 palavras, incluindo tabelas, figuras, notas e referências. São permitidos, no máximo, 5 (cinco) autores por artigo. Todos os artigos aprovados serão traduzidos e publicados nas três línguas: português, inglês e espanhol.

Os artigos que contiverem Tabelas ou Figuras, estas devem estar em formato que permitam ser editadas. Caso algumas dessas Tabelas ou Figuras tenham sido importadas de outros programas, como Excel, Power Point etc., deve ser enviado também o arquivo de origem como Arquivo Complementar.

Não usar expressões como id., ibid., op. cit., loc. cit. e assemelhadas, ou notas de referência e de rodapé. São admitidas notas no final do texto, no entanto, devem ser evitadas.

A submissão dos artigos deve ser de forma eletrônica pelo site www.repec.org.br. Ao final da submissão será enviada mensagem eletrônica por e-mail com a confirmação do recebimento do artigo.

\section{Conteúdo e Formatação dos Artigos}

Para submissão, os artigos devem conter:

- o título no idioma de origem do artigo (português, inglês ou espanhol) sem identificação do(s) autor(es);

- um resumo no idioma de origem do artigo (português, inglês ou espanhol) em no mínimo 150 e máximo de 250 palavras, espaço simples entre linhas, em um único parágrafo e sem entrada de parágrafo. Ao final do resumo devem ser inseridas de três a cinco palavras-chave;

- o artigo propriamente dito redigidos em português, inglês ou espanhol, com no mínimo 5.000 e máximo 10.000 palavras, incluindo tabelas, figuras, notas e referências.

- As páginas dos artigos devem estar devidamente numeradas no canto superior direito, digitadas em editor de texto Word for Windows, nas seguintes condições: 
- $\quad$ papel formato A4 (210 x $297 \mathrm{~mm})$;

- $\quad$ fonte Times New Roman, tamanho 12;

- espaço entre linhas: simples;

- $\quad$ entrada de parágrafo: 1,25 ;

- margens: superior $3 \mathrm{~cm}$, inferior $2 \mathrm{~cm}$, esquerda $3 \mathrm{~cm}$, direita $2 \mathrm{~cm}$;

- tabelas e figuras em fonte Times New Roman, tamanho 10;

- $\quad$ as citações e referências devem obedecer as normas atuais da APA (American Psychological Association).

\section{Tabelas e Figuras ${ }^{1}$}

As tabelas e figuras devem ser usadas nos artigos sempre que suas informações tornarem a compreensão do texto mais eficiente, sem que haja repetição das informações já descritas no texto.

\subsection{Tabelas}

A tabela normalmente deve mostrar valores numéricos ou informação textual organizados em uma exposição ordenada de colunas e linhas. Qualquer outra demonstração textual deve ser caracterizada como figura.

A tabela deve ser apresentada com suas informações de forma visível e suficientes para sua compreensão e deve ser formatada da seguinte forma:

\begin{tabular}{|ll|}
\hline Editor de tabelas & $\begin{array}{l}\text { Word for Windows } 97 \text { ou posterior. Caso os autores tenham elaborado suas tabelas no } \\
\text { programa Excel ou similares, por favor refaçam as tabelas utilizando o recurso em Word. }\end{array}$ \\
\hline Fonte & Times New Roman, tamanho 10. \\
\hline Espaçamento entre linhas & Simples. \\
\hline Espaçamento antes e depois & 3 pt. \\
\hline Cores em tabelas & Utilizar apenas as cores preto e branco (escala de cinza). \\
\hline Título & O título de tabela precisa ser breve, claro e explicativo. Ele deve ser colocado acima da \\
& $\begin{array}{l}\text { tabela, no canto superior esquerdo, e na linha seguinte, logo abaixo da palavra Tabela } \\
\text { (com a inicial maiúscula), acompanhada do número que a designa. As tabelas são }\end{array}$ \\
& $\begin{array}{l}\text { apresentadas com números arábicos de forma sequencial e dentro do texto como um } \\
\text { todo. Ex.: Tabela 1, Tabela 2, Tabela } 3 \text { etc. }\end{array}$ \\
\hline Citação de tabelas & $\begin{array}{l}\text { Ao citar tabelas no corpo do texto escrever apenas o número referente à tabela, por } \\
\text { exemplo: Tabela 1, Tabela 2, Tabela } 3 \text { etc. (a palavra 'Tabela' deverá ser apresentada } \\
\text { com a primeira letra maiúscula). Nunca escreva 'tabela abaixo', 'tabela acima' ou ainda, } \\
\text { 'tabela da página XX', pois a numeração das páginas do artigo pode alterar-se durante } \\
\text { sua diagramação final. }\end{array}$ \\
\hline A fonte utilizada nas notas da tabela deve ser Times New Roman, tamanho 10, \\
espaçamento simples. \\
As notas devem ser descritas no rodapé da tabela e servem para indicar a Fonte das \\
informaços da tabela, além de outras informaços importantes para o entendimento \\
da tabela.
\end{tabular}

1 Grande parte dessas orientações foi adaptada do Manual de Submissão da Revista de Administração Contemporânea - RAC, disponível em www.anpad.org.br. 


\subsection{Figuras}

A figura deve evidenciar um fluxograma, um gráfico, uma fotografia, um desenho ou qualquer outra ilustração ou representação textual.

A figura deve ser apresentada com suas informações de forma visível e suficientes para sua compreensão e deve ser formatada da seguinte forma:

\begin{tabular}{|ll|}
\hline Fonte & Times New Roman, tamanho 10. \\
\hline Cores em figuras & Utilizar apenas as cores preta e branca (escala de cinza). \\
\hline Formato & Encaminhar as figuras em formato editável. \\
\hline Título & $\begin{array}{l}\text { Explica a Figura de maneira concisa, mas discursiva. O título deve ser colocado sob a figura } \\
\text { e numerado com números arábicos de forma sequencial, precedido pela palavra Figura } \\
\text { (com a inicial maiúscula). Ex.: Figura 1, Figura 2, Figura 3, etc. Depois do título, quaisquer } \\
\text { outras informações necessárias para esclarecimentos da figura ou fonte devem ser } \\
\text { acrescidas como Nota. }\end{array}$ \\
\hline Legenda & $\begin{array}{l}\text { A legenda é a explicação dos símbolos utilizados na figura e deve ser colocado dentro dos } \\
\text { limites da figura. }\end{array}$ \\
\hline Tamanho e proporção & $\begin{array}{l}\text { As figuras devem ajustar-se às dimensões do periódico. Portanto uma figura deve ser } \\
\text { elaborada ou inserida no artigo de modo a poder ser reproduzida na largura de uma } \\
\text { coluna ou página do periódico em que ele será submetido. }\end{array}$ \\
\hline Citação no corpo do texto & $\begin{array}{l}\text { Ao citar uma figura no corpo do texto escreva apenas o número referente a figura, por } \\
\text { exemplo: Figura 1, Figura 2, Figura } 3 \text { etc. (a palavra 'Figura' deverá ser apresentada com } \\
\text { a primeira letra em maiúsculo). Nunca escreva 'figura abaixo', figura acima', ou ainda, } \\
\text { 'figura da página XX', pois a numeração das páginas do artigo pode-se alterar durante sua } \\
\text { diagramação final. }\end{array}$ \\
\hline
\end{tabular}

\section{Citações e Referências}

Para acessar a versão completa das normas de citações e referências de acordo com a APA (American Psychological Association) clique aqui. 